\title{
PEMANFAATAN DATA CITRA SATELIT SENTINEL-1 UNTUK PEMANTAUAN SEBARAN TUMPAHAN MINYAK DI WPP 713
}

\section{UTILIZATION OF SENTINEL-1 SATELLITE IMAGE DATA FOR MONITORING OF OIL SPILL IN WPP 713}

\author{
Komang Iwan Suniada \\ Balai Riset dan Observasi Laut \\ Kementerian Kelautan dan Perikanan \\ e-mail : komang.suniada@kkp.go.id \\ Diterima tanggal: 24 Agustus 2020 ; diterima setelah perbaikan: 25 Februari 2021 ; Disetujui tanggal: 1 April 2021
}

\begin{abstract}
ABSTRAK
Wilayah Pengelolaan Perikanan (WPP) 713, khususnya Selat Makassar yang merupakan Alur Laut Kepulauan Indonesia (ALKI) II adalah jalur ekonomis yang membelah di tengah Kepulauan Indonesia serta menghubungkan Samudera Pasifik serta Samudera Hindia. Tingginya lalu lintas pada jalur tersebut menyebabkan munculnya resiko pada keamanan negara, pencurian ikan maupun pencemaran lingkungan akibat tumpahan minyak. Salah satu metode yang dapat digunakan untuk memantau tumpahan minyak pada perairan adalah dengan menggunakan data satelit penginderaan jauh, khususnya data SAR (Synthetic Aperture Radar). Kelebihan satelit radar adalah kemampuannya dalam melakukan akuisisi data pada waktu siang ataupun malam hari dan pada segala kondisi cuaca. Selain kemampuan akusisi data, ketersediaan data yang up to date, hingga cakupan data yang luas $(250 \mathrm{~km})$ dengan resolusi yang cukup tinggi $(10 \mathrm{~m})$ menjadikan data Sentinel-1 sangat layak digunakan pada kajian ini. Kajian ini bertujuan untuk mendeteksi tumpahan minyak yang terjadi di WPP 713, khususnya di Selat Makassar dengan memanfaatkan data citra satelit Sentinel-1. Metode yang digunakan untuk mendeteksi tumpahan minyak adalah metode adaptive threshold yang diproses dengan menggunakan software SNAP (Sentinel Application Platform). Sedangkan penghitungan panjang dan luas area tumpahan minyak dilakukan dengan menggunakan metode spasial analisis pada software QGIS. Hasil kajian menunjukkan bahwa di Selat Makassar telah terjadi tumpahan minyak dengan panjang sekitar 11,7 km serta luas tumpahan sekitar 22,8 km². Tumpahan minyak yang ditemukan pada kajian ini menyerupai ciri-ciri dan karakter tumpahan minyak yang disebabkan oleh kapal yang sedang bergerak, sehingga diduga telah terjadi pelanggaran pada wilayah tersebut. Kajian ini menunjukkan bahwa data citra satelit Sentinel-1 terbukti mampu digunakan untuk mendeteksi tumpahan minyak yang terjadi di WPP 713, khususnya di Selat Makassar.
\end{abstract}

Kata kunci: SAR, Sentinel-1, tumpahan minyak, Selat Makassar.

\section{ABSTRACT}

The Makassar Strait which is a part of the Fisheries Management Area (WPP) 713 and the Indonesian Archipelago Sea Channel (ALKI) II is an economic route that connects the Pacific Ocean in north and Indian Ocean at south through the middle of Indonesia archipelago. Highly traffic on this route poses a risks to national security, illegal fishing, and environmental pollution due to oil spills. Remote sensing satellite with SAR (Synthetic Aperture Radar) is a proper instrument to use to monitor oil spills in open water. The advantage of radar satellites is their ability to perform data acquisition during the day or night and in all weather conditions. Beside their acquisition ability, the time-series data availablity and data dimension (250km) and resolution $(10 \mathrm{~m})$ make the Sentinel-1 very suitable to use in this study. The aim of the study is to detect the oil spill using Sentinel-1 in WPP 713, especially in Makassar Strait. Adaptive threshold method in SNAP software was used to detect the oil spill pattern, while the length and area of the oil spill are calculated using the spatial analysis method and processed under QGIS software. The results found an oil spill in Makassar Strait with a length of about $11.7 \mathrm{~km}$ with a total area around $22.8 \mathrm{~km}^{2}$. The spill pattern resemble to the characteristics of an oil spill caused by a moving ship. This study shows that the Sentinel-1 satellite imagery is proven to be able to detect oil spills that occurred in WPP 713, particularly in the Makassar Strait.

Keywords: SAR, Sentinel-1, oil spills, Makassar strait.

Pemanfaatan Data Citra Satelit Sentinel-1 untuk Pemantauan Sebaran Tumpahan Minyak di WPP 713 


\section{PENDAHULUAN}

Wilayah negara kepulauan Indonesia yang terletak di antara dua benua dan dua samudera menjadikan wilayah perairan Indonesia sebagai salah satu jalur pelayaran yang sangat penting untuk menghubungkan kedua area tersebut. Selain menjadi jalur pelayaran internasional, perairan Indonesia juga merupakan penghubung yang sangat penting bagi gugusan pulaupulau besar atau kecil yang tersebar dari barat hingga ke timur. Jalur-jalur pelayaran yang terdapat di dalam wilayah negara kepulauan Indonesia disebut dengan Alur Laut Kepulauan Indonesia (ALKI) yang terbentuk setelah United Nations Convention on the Law of the Sea (UNCLOS) mengakui hak Indonesia sebagai Archipelagic State dan dinyatakan sebagai hukum positif internasional sejak 16 November 1994 (Wahyono, 2007). Berdasarkan hasil sidang pleno Maritime Safety Committee - The International Maritime Organization (IMO) pada 19 Mei 1998 menetapkan bahwa ALKI di wilayah perairan Indonesia terbagi menjadi ALKI I, ALKI II, ALKI IIIA, ALKI IIIB, ALKI IIIC DAN ALKI IIID (Sudini, 2002). ALKI I difungsikan untuk pelayaran dari Laut Cina Selatan melintasi Laut Natuna, Selat Karimata, Laut Jawa, dan Selat Sunda ke Samudera Hindia dan sebaliknya. ALKI cabang I A difungsikan untuk pelayaran dari Selat Singapura melalui Laut Natuna dan sebaliknya. Jalur pada ALKI II ini difungsikan untuk pelayaran dari Laut Sulawesi melintasi Selat Makasar, Selat Lombok menuju Samudera Hindia dan sebaliknya. Jalur pada ALKI IIIA difungsikan untuk pelayaran dari Samudera Pasifik melintasi Laut Maluku, Laut Seram, Laut Banda, Selat Ombai, Laut Sawu menuju ke Samudera Hindia. ALKI IIIB untuk pelayaran dari Samudera Pasifik melintasi Laut Maluku, Laut Seram, Laut Banda, dan Selat Leti ke Samudera Hindia dan sebaliknya; ALKI IIIC untuk pelayaran dari Samudera Pasifik melintasi Laut Maluku, Laut Seram, Laut Banda ke Laut Arafura dan sebaliknya; dan ALKI IIID untuk pelayaran dari Samudera Pasifik melintasi Laut Maluku, Laut Seram, Laut Banda, Selat Ombai, dan Laut Sawu ke Samudera Hindia dan sebaliknya.

ALKI II merupakan lintasan laut dalam yang ekonomis dan aman untuk dilalui sehingga menyebabkan jalur tersebut menjadi pilihan utama lintasan internasional kapal-kapal tanker dari utara menuju ke selatan. Meningkatnya pengguna jalur tersebut tentu akan dibarengi dengan beberapa masalah yang kemungkinan akan timbul dan perlu mendapat perhatian, diantaranya : masalah keamanan negara, pencurian ikan maupun masalah lingkungan terutama terkait dengan tumpahan minyak. Resiko terjadinya tumpahan minyak di Selat Makassar, yang merupakan bagian dari ALKI II dan juga bagian dari Wilayah Pengelolaan Perikanan (WPP) 713, selain disebabkan karena kapal-kapal tanker (operasional atau kecelakaan), resiko tumpahan minyak bisa juga disebabkan oleh kilang minyak ataupun aktifitas tambang minyak lepas pantai yang tersebar di sekitar wilayah tersebut. Beberapa kejadian yang menyebabkan tumpahan minyak di wilayah perairan Indonesia, diantaranya adalah tabrakan antara tongkang PLTU-1/PLN yang mengangkut 363 KL IDF dengan kapal kargo An Giang menyebabkan sungai Musi di sekitar Palembang tercemar pada tahun 2003; tumpahan minyak mentah dari Pertamina UP VII Balongan yang mencemari terumbu karang di sekitar Pantai Indramayu tahun 2004; tumpahan minyak dari Perusahaan Total E \& P Ind. Di Balikpapan tahun 2004; meledaknya kapal ikan MV Fu Yuan Fu F66 yang menyebabkan tumpahan minyak ke perairan Teluk Ambon tahun 2005 (Sulistyono, 2013) hingga tahun 2018 pada saat minyak jenis bahan bakar kapal (fuel oil) tumpah di perairan Teluk Balikpapan, tidak jauh dari Refinery Unit V Balikpapan milik PT Pertamina (Persero) serta insiden tumpahan minyak yang cukup besar yang terjadi pada tahun 2019 pada saat pengeboran sumur YYA-1 di Blok ONWJ (Offshore North West Java) milik Pertamina Hulu Energi ONWJ (PHE ONWJ) di Perairan Karawang.

Berbagai metode telah banyak digunakan untuk pengawasan ekosistem perairan laut dari pencemaran tumpahan minyak, salah satunya adalah dengan memanfaatkan data citra satelit (Blondeau-Patissier et al., 2019), baik itu satelit dengan sensor pasif misalnya satelit Landsat (Sihombing et al., 2018), satelit MODIS (Hu et al., 2009) atau sensor aktif misalnya satelit radar (Prastyani \& Basith, 2018; Sulma et al., 2019) ataupun kombinasi antara sensor pasif dan aktif (Sun et al., 2018; Prastyani \& Basith, 2019). Data citra satelit yang umum digunakan untuk mendeteksi tumpahan minyak adalah citra radar atau SAR (Synthetic Aperture Radar). Kelebihan satelit radar yang menggunakan sensor microwave aktif adalah kemampuannya dalam melakukan akuisisi data pada waktu siang ataupun malam hari dan pada segala kondisi cuaca (Lee et al., 1994; Torres et al., 2012; Liu et al., 2016; BlondeauPatissier et al., 2019). Sentinel-1 merupakan satelit radar yang secara konsisten menyediakan data citra SAR pada website Copernicus Open Access Hub, https://scihub.copernicus.eu/. Data-data yang terdapat pada web tersebut, baik itu data arsip maupun data terbaru dapat diunduh dan digunakan secara cumacuma oleh pengguna. Selain konsisten dan tidak 
berbayar, data-data terbaru yang ditampilkan hanya mempunyai jeda waktu maksimal 24 jam dari waktu akuisisi. Kelebihan lain dari Sentinel-1 ini adalah lebar sapuan sensor satelit yang berjarak $250 \mathrm{~km}$ serta resolusi data yang cukup tinggi, yaitu $10 \mathrm{~m}$ (Torres et al., 2012; Liu et al., 2016) menyebabkan satelit Sentinel-1 sangat layak digunakan untuk memantau tumpahan minyak.

Pemantauan tumpahan minyak dengan menggunakan data radar sangat berkaitan dengan kondisi oseanografi dan mekanisme hamburan balik (backscattering) sinyal radar. Salah satu kondisi oseanografi yang paling berpengaruh terhadap backscattering sinyal radar di laut adalah gelombang (Romeiser, 2013). Gelombang akan menyebabkan kekasaran pada permukaan laut, namun tumpahan minyak akan menekan kekasaran permukaan tersebut, sehingga menyebabkan daerah-daerah dengan tumpahan minyak akan menjadi lebih rata. Daerah yang lebih rata akan menyebabkan backscatter yang rendah sehingga daerah tersebut akan tampak lebih gelap pada citra radar. Selain karena tumpahan minyak, area gelap pada citra radar mungkin disebabkan oleh beberapa hal yang menyerupai tumpahan minyak (look-alikes), yaitu : berupa surfaktan alami yang dihasilkan phytoplankton maupun ikan, fenomena hujan, area dengan kecepatan angin rendah dan lain sebagainya (Alpers \& Espedal, 2004), sehingga perlu ketelitian dan kehati-hatian dalam menentukan area tumpahan minyak.
Kajian ini bertujuan untuk mendeteksi tumpahan minyak yang terjadi di WPP 713, khususnya di Selat Makassar dengan memanfaatkan data citra satelit Sentinel-1.

\section{BAHAN DAN METODE}

\section{Lokasi Kajian}

Kajian ini dilakukan di WPP 713, khususnya di Selat Makassar karena jalur tersebut merupakan jalur yang ramai dengan berbagai aktifitas pelayaran, baik itu angkutan barang maupun minyak. Selain itu, pada jalur tersebut terdapat kilang minyak dan pengeboran minyak lepas pantai yang kesemuanya berpotensi menyebabkan terjadinya tumpahan minyak secara sengaja ataupun tidak sengaja. Sebagai catatan, di tahun 2018 telah terjadi kebocoran pipa bawah air pada salah satu kilang minyak milik Pertamina dan menyebabkan pencemaran yang sangat berat di sekitar perairan Balikpapan.

\section{Data}

Kajian ini menggunakan data radar dari satelit Sentinel 1A level 1 dengan mode Interferometric Wide swath (IW), High resolution Ground Range Detected (GRDH), lebar cakupan data adalah $250 \mathrm{~km}$ dengan ukuran pixel $10 \mathrm{~m}$ (Torres et al., 2012; Liu et al., 2016). Data yang digunakan pada kajian ini (Gambar 2) adalah data tanggal 28 Desember 2019 dan diperoleh dari web Copernicus Open Access Hub, https://scihub. copernicus.eu/.

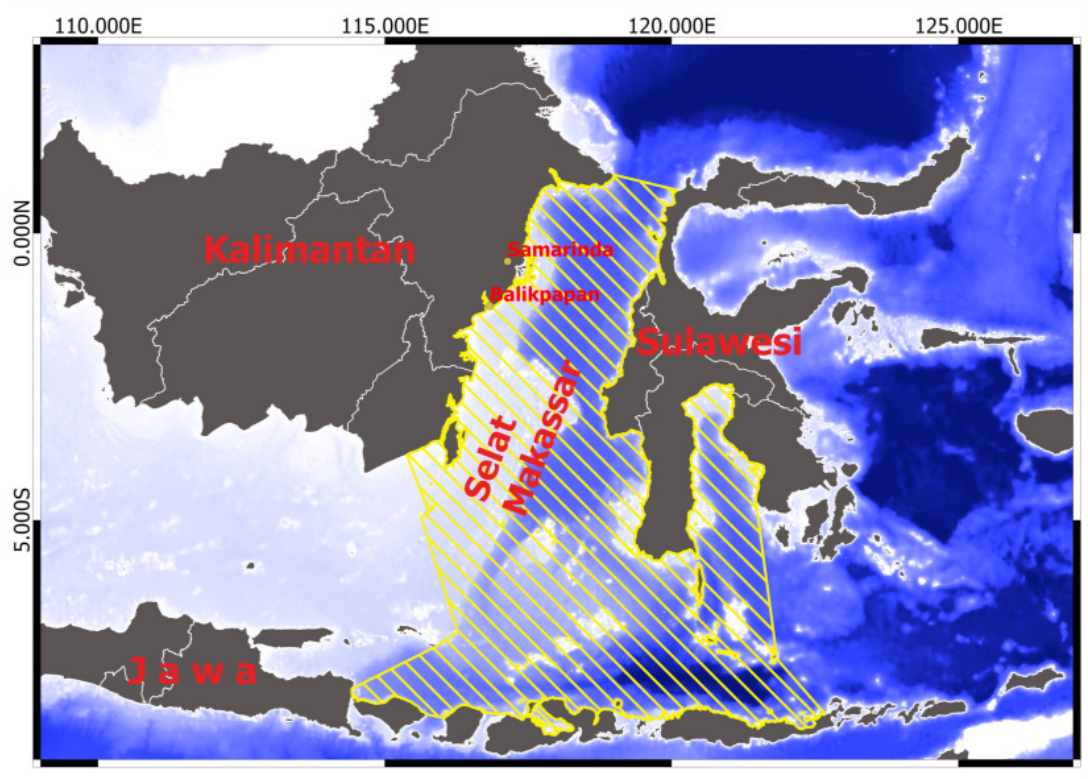

Gambar 1. Lokasi Kajian di WPP 713, khususnya di Selat Makassar. Figure 1. Location of the Study in WPP 713, particularly in the Makassar Strait.

Pemanfaatan Data Citra Satelit Sentinel-1 untuk Pemantauan Sebaran Tumpahan Minyak di WPP 713 


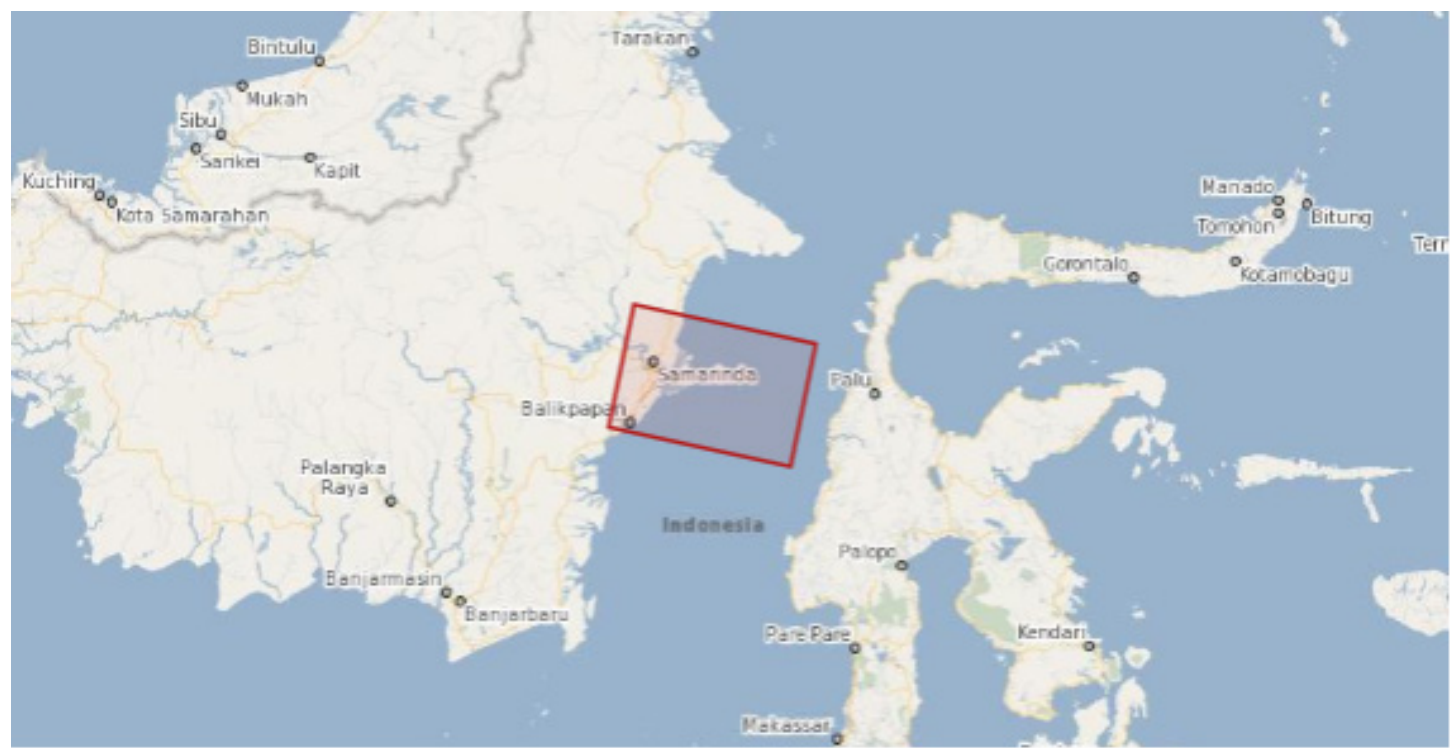

Gambar 1. Lokasi Data Sentinel-1 yang digunakan pada kajian ini.

Figure 1. Location Data Sentinel-1 used in this study.

\section{Analisis Data}

Mengacu pada dokumen RUS (2017), deteksi tumpahan minyak dengan memanfaatkan data citra satelit radar ini terdiri dari beberapa langkah, yaitu :

1. Proses Download Data dari website Copernicus Open Access Hub adalah proses untuk memperoleh data yang seusai dengan waktu dan lokasi kajian.

2. Subset Data adalah proses untuk memotong data (crop) sesuai dengan area kajian (area of interest, AOI) saja dengan maksud agar prosesing data selanjutnya dapat dilakukan dengan lebih cepat.

3. Radiometric Correction dengan menggunakan Speckle filter adalah proses yang dilakukan untuk mengurangi efek 'salt and pepper' yang umumnya terdapat pada data citra radar. Dengan memanfaatkan speckle filter diharapkan dapat mengurangi varians dan error yang terjadi pada citra radar sekaligus berfungsi untuk meningkatkan kualitas dari data citra tersebut. Secara umum terdapat 2 jenis teknik yang digunakan untuk mengurangi noise, yaitu : multi-look process dan spatial filtering. Multi-look process dilakukan pada saat akuisisi data sedangkan spatial filtering dilakukan setelah data berhasil disimpan pada media penyimpanan. Prinsip dasar pengurangan noise (speckle filtering) adalah meningkatkan kualitas data citra radar dengan mengurangi noise (Filipponi, 2019), namun informasi penting seperti sudut-sudut pada data (edge), informasi radiometrik, fitur-fitur linear (misalnya jalan), titik-titik target, teksture serta resolusi spasial tetap dapat dipertahankan (Mansourpour et al., 2006).
4. Oil Spill Mapping adalah proses untuk mengidentifikasi tumpahan minyak yang terjadi pada perairan. Tahap ini merupakan tahap yang harus dilakukan dengan hati-hati mengingat terdapat beberapa fenomena yang menyerupai tumpahan minyak seperti yang telah disebutkan sebelumnya.

5. Geometric Correction adalah langkah yang digunakan untuk memproyeksikan data tumpahan minyak yang telah disusun sebelumnya kedalam sistem referensi koordinat bumi. Koreksi yang digunakan adalah Ellipsoid Correction.

6. Menghitung Area Oil Spill adalah proses untuk mengetahui area yang mencakup panjang serta luasan tumpahan minyak yang terjadi pada lokasi kajian.

7. Langkah 2 sampai 5 dilakukan pada software SNAP (Sentinel Application Platform) sedangkan langkah 6 dilakukan pada software QGIS (Quantum GIS) dimana kedua software tersebut merupakan software open source yang tidak berbayar.

8. Pada awalnya, software SNAP merupakan software pengolah data citra satelit yang didedikasikan untuk citra satelit Sentinel. Namun dalam perkembangannya, software ini bisa juga digunakan untuk mengolah berbagai jenis data citra satelit yang lain. Selain mampu memproses beberapa jenis data citra satelit, desain software SNAP yang flexible dan inovatif menjadikannya sangat ideal untuk analisis serta observasi fenomena-fenomena yang terjadi di bumi. 


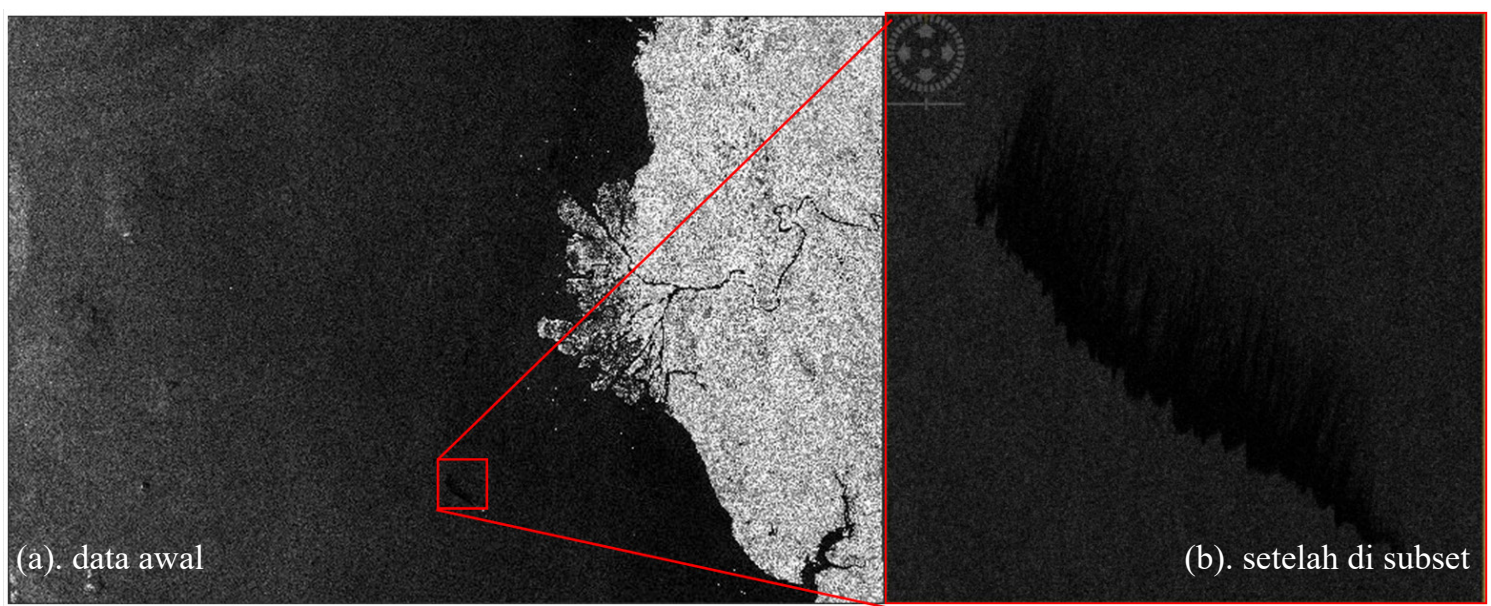

Gambar 3. Tampilan data citra SAR Sentinel-1 pada software SNAP.

Figure 3. Display of SAR Sentinel-1 image data on SNAP software.

\section{HASIL DAN PEMBAHASAN}

Data 28 Desember 2019 yang dijadikan sebagai data dasar pada kajian ini mempunyai kode S1A_IW_GR DH_1SDV_20191228T215104_20191228T21512 9_030554_037FDE_56E3. Tampilan awal data ini ketika di import kedalam software SNAP akan tampak seperti pada gambar 3a dibawah. Setelah proses import berhasil dilakukan, maka proses selanjutnya adalah proses pengolahan data untuk menghasilkan informasi tumpahan minyak. Namun, pengolahan data dengan menggunakan data utuh akan memerlukan waktu yang cukup panjang serta membutuhkan perangkat komputer dengan spefikiasi yang cukup tinggi karena ukuran datanya cukup besar. Untuk mengatasi permasalahan tersebut perlu dilakukan pemotongan data (crop/subset) terlebih dahulu dengan mengkhususkan pada area kajian saja, sehingga ukuran data menjadi lebih kecil. Untuk kajian ini, subset dilakukan pada lokasi yang terdapat tumpahan minyaknya, yaitu pada koordinat $\mathrm{N}$ :-1,182; W : 117,787; S : 1,264; E : 117,662. Setelah dilakukan proses subset, tampilan data akan menjadi seperti yang terlihat pada gambar $3 \mathrm{~b}$.

Seperti sudah disampaikan sebelumnya, data radar sangat identik dengan speckle noise atau yang biasa disebut dengan salt and pepper noise. Noise tersebut terjadi karena terdapatnya banyak pantulan sinyal dari permukaan bumi yang saling mengganggu satu dengan lainnya dan menyebabkan data citra menjadi lebih sulit untuk diinterpretasikan dan dianalisis lebih lanjut (Qiu et al., 2004) Pada default software SNAP, filter yang digunakan untuk mengurangi noise ini adalah Lee Sigma filter dengan ukuran 7x7. Lee et al., (1994) menyatakan bahwa filter ini masih yang terbaik digunakan untuk interpretasi visual karena mampu mempertahankan sudut, fitu-fitur linear serta informasi teksture pada data radar. Lee Sigma juga memiliki karakteristik menghaluskan area di dekat tepi tanpa membuat blur karena hanya piksel di satu sisi yang dirata-rata serta mampu mempertahankan fitur linier seperti jalan dengan lebar 1 hingga 3 piksel (Indriasari et al., 2020). Kiran \& Anjaneyulu (2014) menyatakan bahwa penggunaan filter dapat menyesuaikan dengan kebutuhan karena semakin besar ukuran filter yang digunakan memang akan membuat noise semakin berkurang namun ketajaman data juga akan berkurang. Hasil koreksi radiometric untuk pengurangan noise yang dilakukan dengan menggunakan default parameter yang terdapat pada software SNAP menunjukkan bahwa data radar menjadi lebih kontras sehingga perbedaan antara permukaan air dan tumpahan minyak menjadi terlihat lebih jelas (gambar 4).

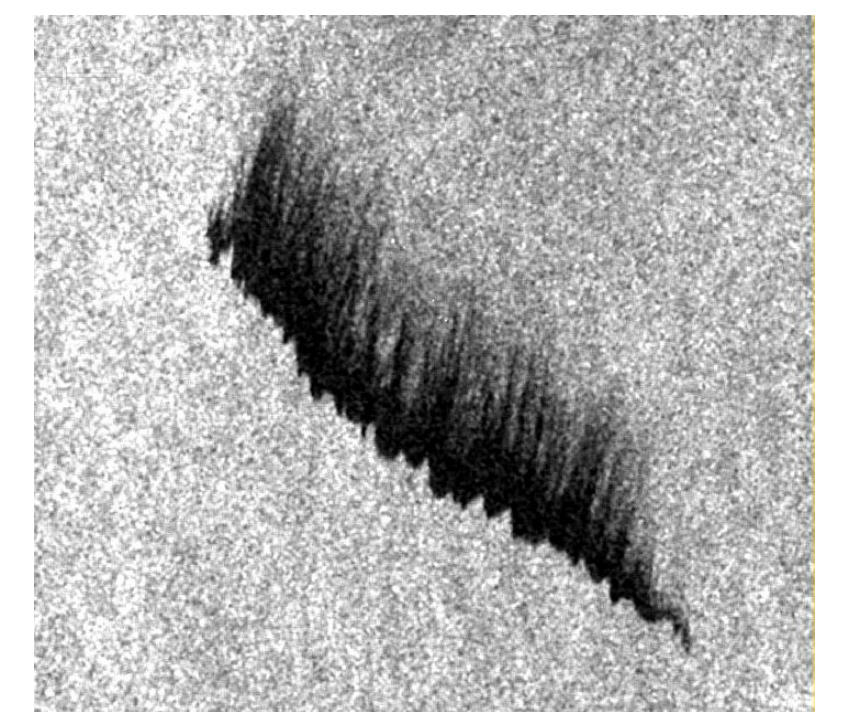

Gambar 4. Hasil koreksi speckle filter pada software SNAP. Figure 4. Result of speckle filter correction in SNAP software.

Pemanfaatan Data Citra Satelit Sentinel-1 untuk Pemantauan Sebaran Tumpahan Minyak di WPP 713 

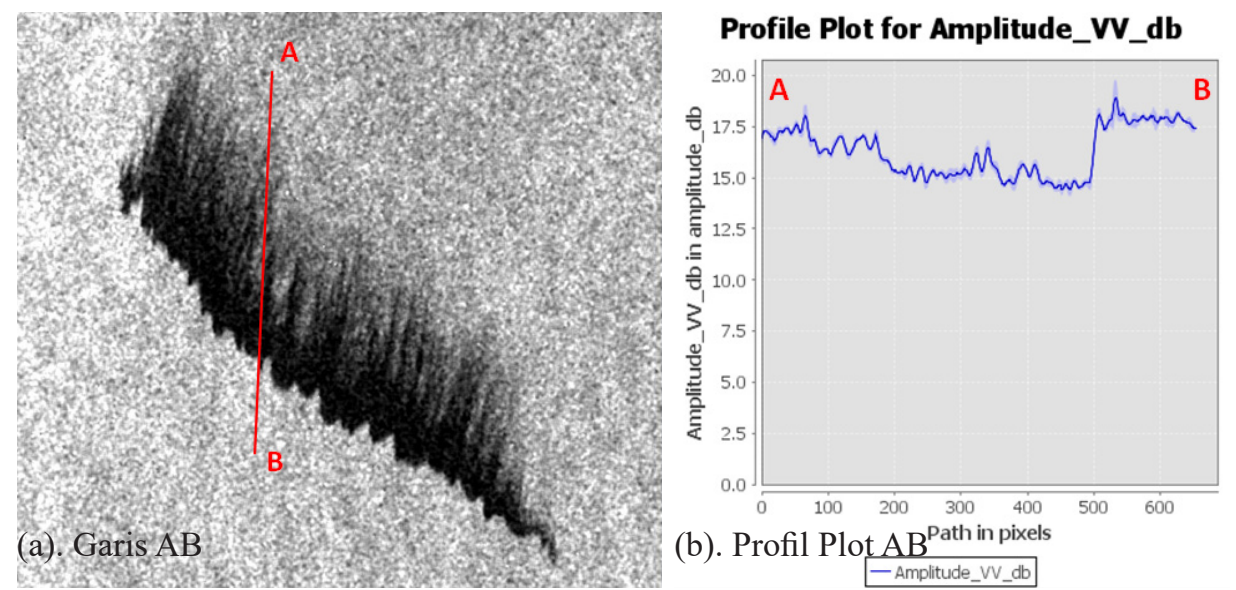

(b). Profil Plot $A B^{\text {Path in pixels }}$

Gambar 5. Profile Plot antara tumpahan minyak dan air.

Figure 5. Profile Plot between oil and water spills.

Untuk dapat memberikan informasi mengenai luasan tumpahan minyak, nilai-nilai pixel yang mengandung tumpahan minyak harus diekstrak terlebih dahulu. Daerah yang terkontaminasi dengan tumpahan minyak akan selalu berwarna lebih gelap pada citra radar karena mempunyai nilai reflectance yang lebih rendah jika dibandingkan dengan air yang tidak terkontaminasi tumpahan minyak (Blondeau-Patissier et al., 2019; Chaturvedi et al., 2020).

Untuk mengetahui nilai reflectance pada daerah tumpahan minyak dan sekitarnya, sebuah garis $\mathrm{AB}$ ditarik melewati tumpahan minyak dan air (gambar 5a) lalu nilainya ditampilkan pada grafik. Profil plot pada gambar $5 \mathrm{~b}$ menunjukkan bahwa perbedaan nilai antara air dan tumpahan minyak pada pixel 500 kebawah adalah sangat kecil, yaitu sekitar lebih kurang $1 \mathrm{db}$. Berbeda dengan nilai air dan tumpahan minyak pada sekitar pixel ke-500, dimana reflectance antara air dan tumpahan minyak terlihat cukup jelas, yaitu berbeda sekitar lebih kurang 2,5 db. Perbedaan reflectance diantara kedua titik $\mathrm{AB}$ ini memberikan informasi bahwa lapisan minyak didekat titik B lebih pekat daripada lapisan minyak didekat titik A. Dengan mengetahui bahwa threshold antara air dan tumpahan minyak pada data ini adalah antara $1-2,5 \mathrm{db}$, maka nilai threshold tersebut akan digunakan untuk mengekstrak piksel-piksel yang terkontaminasi dengan tumpahan minyak. Pendekatan yang digunakan untuk mendeteksi tumpahan minyak ini disebut dengan pendekatan yang menggunakan algoritma adaptvie threshold. Langkah ini tersedia pada toolbox yang bernama oil spill detection pada software SNAP. Prinsip dasar oil spill detection toolbox ini adalah menyusun piksel gelap pada permukaan laut yang di duga sebagai tumpahan minyak dengan cara mengidentifikasi, membedakan serta mengelompokkan nilai-nilai piksel pada data citra radar berdasarkan luasan cluster dan thershold yang dinput oleh pengguna pada software SNAP (RUS, 2017; Prastyani \& Basith, 2018).

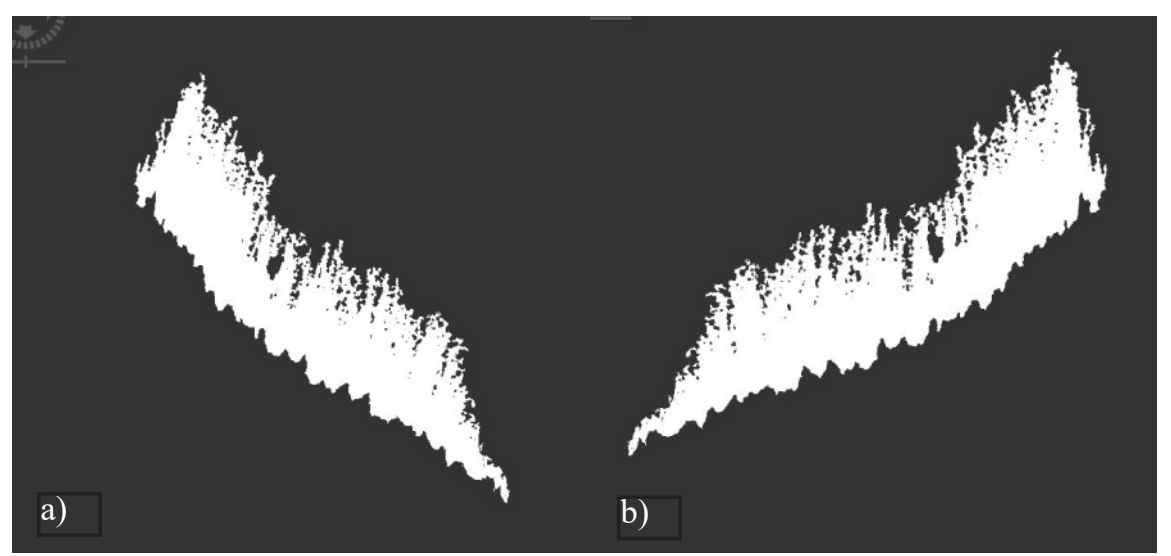

Gambar 6. Koreksi Geometrik pada software SNAP. (a). sebelum koreksi; (b). setelah koreksi Figure 6. Geometric Correction in SNAP software. (a). before correction; (b). after correction 


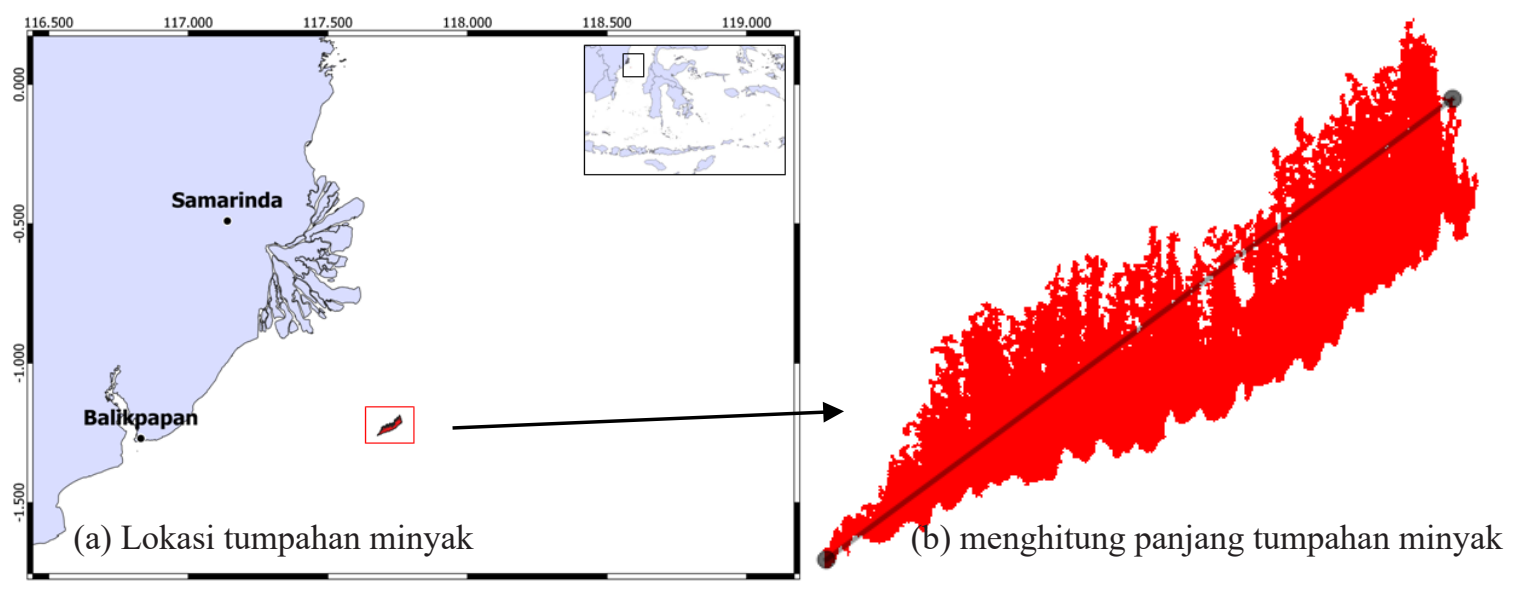

Gambar 7. Tumpahan minyak pada tanggal 28 Desember 2019.

Figure 7. Oil spill on December 28, 2019.

Setelah informasi tumpahan minyak berhasil diekstrak (gambar 6a), maka proses selanjutnya adalah koreksi geometri yaitu proses untuk memproyeksikan data tumpahan minyak tersebut kedalam referensi koordinat bumi. Proses transformasi data Sentinel-1 kedalam proyeksi peta merupakan hal yang sangat penting untuk dilakukan karena setelah diproyeksikan, informasi dari data Sentinel-1 akan memungkinkan untuk di tumpang-susunkan (overlay) dengan sumber informasi lainnya misalnya informasi digital elevation model (DEM), data geographycal information system (GIS) atau data radar yang lain (Small \& Schubert, 2019). Hasil koreksi geometrik dengan menggunakan parameter default Ellipsoid Correction serta proyeksi WGS 84 pada software SNAP menunjukkan bahwa posisi tumpahan minyak yang sebenarnya adalah berkebalikan dari posisi pada data awal (gambar 6b). Untuk mengetahui informasi mengenai panjang maupun luasan tumpahan minyak digunakan software image processing yang lain, yaitu QGIS. Sebelum bisa terbca di software QGIS, data tumpahan minyak yang telah dikoreksi ini harus di export terlebih dahulu kedalam format TIFF yang dilengkapi dengan geo-location. TIFF (Tagged Image File Format) adalah format file berbasis tag (penanda lokasi) untuk menyimpan data raster ataupun untuk memudahkan pengolahan lebih lanjut. Keunggulan utama dari file berformat TIFF ini adalah dapat dipergunakan pada berbagai macam software aplikasi serta tidak tegantung oleh jenis komputer, jenis sistem operasi maupun jenis hardware grafis. Ukuran filenya yang kecil mampu menyimpan informasi hitam-putih, greyscale hingga gambar berwarna akan memudahkan pengguna menyesuaikan dengan karakteristik scanner, monitor maupun printer (Mahammad \& Ramakrishnan, 2003).

Data tumpahan minyak yang diinput kedalam software QGIS lalu dioverlay dengan basemap Indonesia agar lokasi kejadian dapat diketahui dengan lebih jelas. Hasil overlay menunjukkan bahwa kejadian tumpahan minyak terjadi di sebelah timur kota Balikpapan (gambar 7a). Proses penting lain yang bisa dilakukan pada software QGIS adalah memberikan informasi mengenai panjang tumpahan minyak serta menghitung area (luasan) dari tumpahan minyak tersebut. Dalam pedoman pelaksanaan penanggulangan dan ganti

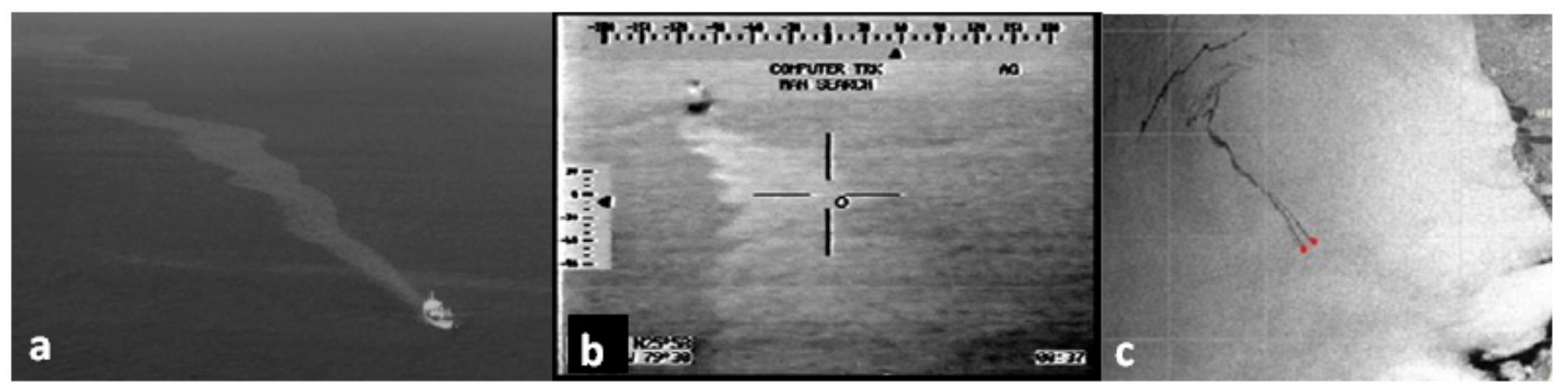

Gambar 8. Pola sebaran tumpahan minyak dari kapal.

Figure 8. The pattern of distribution of oil spills from ships. 
kerugian dampak tumpahan minyak terhadap sumber daya ikan yang dikeluarkan oleh Kementerian Kelautan dan Perikanan, salah satu informasi penting harus diketahui dalam kasus tumpahan minyak yang terjadi di perairan Indonesia adalah informasi mengenai panjang dan luasan area terdampak oleh tumpahan minyak. Pada kajian ini proses penghitungan panjang tumpahan minyak dilakukan dengan analisis spasial, yaitu dengan menggunakan menu measure yang terdapat pada software QGIS. Panjang tumpahan minyak dapat diukur dengan cara menarik garis lurus dari ujung ke ujung melintasi area tumpahan minyak (gambar 7b). Hasil pengukuran dengan menggunakan software QGIS pada kajian ini menunjukkan bahwa panjang tumpahan minyak adalah sekitar 11.726 meter atau $11,726 \mathrm{~km}$.

Penghitungan luas area tumpahan minyak dilakukan dengan menggunakan analisis spasial dengan terlebih dahulu melakukan konversi pada data tumpahan minyak. Konversi yang dilakukan adalah mengubah dari format raster menjadi format vektor atau disebut proses vectorized. Setelah selesai dikonversi kedalam format vektor, lalu dengan menggunakan perintah '\$area' pada data atribut tabel maka software QGIS akan secara otomatis menghitung luasan data tumpahan minyak tersebut. Hasil penghitungan memberikan informasi bahwa luas tumpahan minyak pada kajian ini adalah sekitar $22.837 .400 \mathrm{~m}^{2}$ atau sekitar $22,8 \mathrm{~km}^{2}$. Karena validasi lapangan tidak dilakukan, maka pendekatan yang dilakukan untuk validasi adalah dengan menggunakan data-data sekunder yang mendukung. Dari analisis secara visual terlihat bahwa pola tumpahan minyak pada kajian ini memiliki bentuk memanjang yang menyerupai ciri-ciri dan karakter tumpahan minyak yang disebabkan oleh kapal yang sedang bergerak, seperti yang terlihat pada gambar 8a (European Maritime Safety Agency, 2012); gambar 8b (Colak \& Can, 2011) dan gambar 8c (Kordzadze \& Demetrashvili, 2018)

Secara umum, tumpahan minyak yang terjadi di laut disebabkan oleh tumpahan yang berasal dari operasional kapal yang biasanya terdiri dari produk limbah berminyak dari bahan bakar dan minyak pelumas yang berasal dari operasional mesin kapal, limbah air yang mengandung minyak yang berasal dari operasional rutin lainnya serta sisa-sisa minyak mentah atau minyak olahan yang terdapat pada tangkitangki penyimpanan pada kapal tanker (Colak \& Can, 2011). Selain dari operasional kapal, tumpahan minyak bisa disebabkan karena ketidaksengajaan, yaitu karena terjadinya kecelakaan (White \& Molloy,
2003) ataupun terjadinya bencana alam yang tidak diinginkan (Coastal Response Research Center, 2016). Pembuangan minyak secara sengaja atau ilegal dari operasional kapal-kapal besar memang mempunyai volume yang lebih kecil jika dibandingkan dengan tumpahan minyak akibat kecelakaan atau bencana alam sehingga kurang mendapat perhatian serius dari instansi berwenang, namun European Maritime Safety Agency (2012) menyatakan bahwa efek kumulatif dari pembuangan minyak yang lebih kecil selama periode waktu yang panjang akan memberikan kontribusi nyata bagi kerusakan lingkungan serta mahluk hidup yang terdapat di dalamnya.

\section{KESIMPULAN DAN SARAN}

Data citra satelit Sentinel-1 terbukti mampu digunakan untuk mendeteksi tumpahan minyak yang terjadi di WPP 713, khususnya di Selat Makassar. Kemampuan ini dapat digunakan sebagai salah satu alternatif untuk melakukan kegiatan pemantauan yang terkait dengan pembuangan limbah minyak secara ilegal di seluruh wilayah perairan Indonesia. Dengan adanya pemantauan yang berkala serta tindakan hukum yang lebih tegas, diharapkan pelanggaran-pelanggaran tersebut dapat berkurang sehingga lingkungan laut beserta mahluk hidup di dalamnya dapat terjaga dengan baik.

\section{UCAPAN TERIMA KASIH}

Kepala Balai, Ketua Kelompok Peneliti serta rekanrekan peneliti di Balai Riset dan Observasi Laut atas dukungan dan kerjasamanya selama kajian hingga penulisan KTI ini. The European Space Agency (ESA) melalui web Copernicus Open Access Hub dan web science toolbox exploitation platform sebagai penyedia data citra satelit Sentinel dan software pengolah data SNAP yang tidak berbayar, serta web QGIS.org yang menyediakan software pengolah data QGIS sehingga kajian ini dapat terlaksana.

\section{DAFTAR PUSTAKA}

Alpers, W., \& Espedal, H. (2004). "Oils and Surfactants." Synthetic Aperture Radar Marine User's Manual, C. R. Jackson and J. R. Apel, eds., National Oceanic and Atmospheric Administration, Washington DC. P.263-276.

Blondeau-Patissier, D., Schroeder, T., Irving, P., Witte, C., \& Steven, A. (2019). Satellite detection of 
oil spills in the Great Barrier Reef using the Sentinel-1, -2 and -3 satellite constellations - A technical assessment of a synergistic approach using SAR, optical and thermal information. CSIRO, Australia.

Chaturvedi, S. K., Banerjee, S. \& Lele, S. (2020). An Assessment of Oil Spill Detection Using Sentinel 1 SAR-C Images. Journal of Ocean Engineering and Sciences, 5(2), 116-135.

Coastal Response Research Center. (2016). 2016 NRPT: Natural Disaster Causing Technology Disaster in Mobile Bay Area. A Workshop Report. Research Institute, Centers and Programs - University of New Hampshire.

Colak, T. I., \& Can, S. (2011). Ship Based Oil Pollution for Black Sea. Proceeding of the $1^{\text {st }}$ International Symposium on Naval Architecture and Maritime. P.75-84.

European Maritime Safety Agency. (2012). Addressing Illegal Discharges in the Marine Environment. (Available at http://www.emsa.europa.eu/ damage-stability-study/items.html?cid $=77 \&$ id $=$ 1879).

Filipponi, F. (2019). Sentinel-1 GRD Preprocessing Workflow. Proceeding of $3^{\text {rd }}$ International Electronic Conference on Remote Sensing. 18(1), 1-4.

Hu, C., Li, X., Pichel, W. G., \& Muller-Karger., F. E. (2009). Detection of Natural Oil Slicks in NW Gulf of Mexico using MODIS Imagery. Geophysical Research Letters, 36(1), 1-5.

Indriasari, N., Arief, R., Kustiyo., Budiono, M. E., Dyatmika, H. S., Rahayu, M. I., Payani, A. S. Amriya, Q., Maulana, R., \& Ali, S. (2020). Analisa Filter Speckle Single and Multitemporal Data Sentinel 1-A. Proceeding of The Fifth International Conferences of Indonesian Society for Remote Sensing - IOP Publishing, 1-10.

Kiran, D., \& Anjaneyulu, L. (2014). Estimating the Performance of Speckle Filters on RADARSAT-2 and ALOS PALSAR-2 Data. Proceeding of the 10th International Conference on Microwave, Antenna, Propagation and Remote Sensing. 313-318.
Kordzadze, A. A., \& Demetrashvili, D. I. (2018). Pollution of the Black Sea by Oil Products : Its Monitoring and Forecasting. Journal of the Georgiam Geophysical Society : Physics of Solid Earth, Atmosphere, Ocean and Space Plasma, 21(2), 47-60.

Lee, J.S., Jurkevich, I., Dewaele, P., Wambacq, P., \& Oosterlinck, A. (1994). Speckle Filtering of Synthetic Aperture Radar Images : A Review. Remote Sensing Reviews, 8(4), 313-340.

Liu, C., Velde, R., \& Vekerdy, Z. (2016). Analysis of Sentinel-1 SAR Data for mapping standing water in the Twente region. Thesis. University of Twente.

Mahammad, S. S., \& Ramakrishnan, R. (2003). GeoTIFF - A Standard Image File Format for GIS Applications. Map India 2003 Conference.

Mansourpour, M., Rajabi, M., \& Blais. (2006). Effects and performance of speckle noise reduction filters on active radar and SAR images. Proceeding of International Society for Photogrammetry and Remote Sensing, Vol.36-1.

Prastyani, R., \& Basith, A. (2018). Utilisation of Sentinel-1 SAR Imagery for Oil Spill Mapping : A case Study of Balikpapan Bay Oil Spill. Journal of Geospatial Information Science and Engineering (JGISE), 1(1), 22-26.

Prastyani, R., \& Basith, A. (2019). Deteksi Tumpahan Minyak di Selat Makassar dengan Penginderaan Jauh Sensor Aktif dan Pasif. Jurnal Geodesi dan Geomatika Elipsoida, 2(1), 88-94.

Qiu, F., Berglund, J., Jensen, J.R., Thakkar, P, \& Ren, D. (2004). Speckle Noise Reduction in SAR Imagery Using a Local Adaptive Median Filter. GIScience and Remote Sensing, 41(3), 244-266.

Romeiser, R. (2013). The Future of SAR-Based Oceanography: High-resolution current measurements by along-track interferometry. Oceanography 26(2), 92-99. http://dx.doi. org/10.5670/oceanog. 2013.37.

RUS - The Research and User Support for Sentinel core products (RUS). (2017). Training Kit OCEA03 : Oil Spill Mapping with Sentinel-1. Available at https://rus-copernicus.eu/portal/ 
wp-content/uploads/library/education/training/

OCEA03_OilSpill_Kuwait_Tutorial.pdf.

Small, D., \& Schubert, A. (2019). Guide to Sentinel-1 Geocoding. University of Zurich. 42P.

Sihombing, V. L., Putra, I. D. N. N., \& Sasmita, G. M. A. (2018). Aplikasi Deteksi Tumpahan Minyak dengan Interpretasi Citra Satelit Landsat 8. Jurnal MERPATI, 6(3), 244-251.

Sudini, L. P. (2002). Penetapan Alur-alur Laut Kepulauan Menurut Konvensi Hukum Laut 1982. Jurnal Hukum dan Pembangunan, 32(3). 303-327.

Sulistyono. (2013). Dampak Tumpahan Minyak (Oil Spill) di Perairan Laut pada Kegiatan Industri Migas dan Metode Penanggulangannya. Forum Teknologi, 3(1), 49-57.

Sulma, S., Rahmi, K. I. N., Febrianti, N., \& Sitorus, J. (2019). Deteksi Tumpahan Minyak Menggunakan Metode Adaptive Threshold dan Analisis Tekstur pada Data SAR. Majalah Ilmiah Globe, 21(1), 45-52.

Sun, S., Hu, C., Garcia-Pineda, O., Kourafalou, V., Henaff, M. L., \& Androulidakis, Y. (2018). Remote Sensing Assessment of Oil Spills near a Damaged Platform in the Gulf of Mexico. Marine Pollution Buletin, 13, 141-151.

Torres, R., Snoeij, P., Davidson, M., Bibby, D., \& Lokas, S. (2012). The Sentinel-1 mission and its application capabilities. IEEE International Geoscience and Remote Sensing Symposium, 2012, 1703-1706. doi: 10.1109/ IGARSS.2012.6351196..

Wahyono, S.K. (2007) Indonesia Negara Maritim. Jakarta: Teraju (Anggota IKAPI).

White, I. C. and F. C. Molloy. 2003. Factors That Determine The Cost of Oil Spills. Proceedings of International Oil Spill Conference. 1-15. 